\title{
Smartirrigation Apps: Urban Turf ${ }^{1}$
}

\author{
Haimanote K. Bayabil, K. W. Migliaccio, J. H. Debastiani Andreis, C. Fraisse, K. T. Morgan, and G. \\ Vellidis ${ }^{2}$
}

\section{Introduction}

According to a report by the National Turfgrass Federation, the US national turfgrass industry covers more area than any crop (Figure 1) and is valued at $\$ 40$ billion, with turfgrass being used on more than 700,000 athletic fields around the country. It also offers a variety of job opportunities in seed and sod production, lawn care, and landscaping. Florida's turf industry ranks number one in the country with a total acreage of close to 4 million acres and economic activity of $\$ 7.82$ billion, supporting about 173,000 jobs.

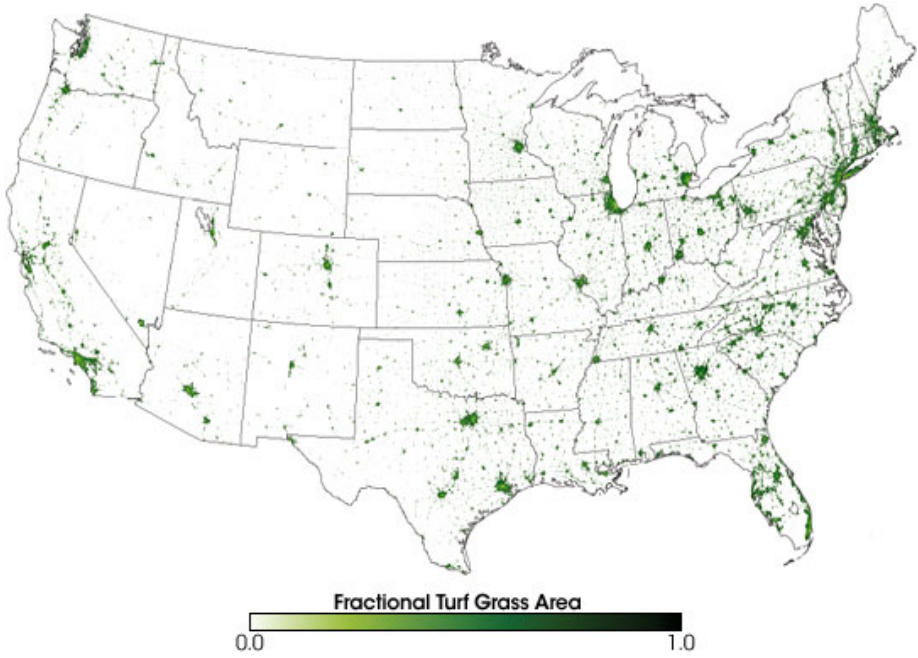

Figure 1. Fractional area coverage of turfgrass (\%) in the US. Credits: NASA (https://earthobservatory.nasa.gov/features/Lawn/ lawn2.php)

\section{Turf Irrigation}

While adequate irrigation is critical for optimal turf growth, excess irrigation will result in waste of freshwater, leaching and/or runoff of nutrients, and pollution of freshwater bodies. Efficient irrigation conserves freshwater and also contributes to best management of nutrients to minimize nutrient loading to water bodies. Advancements of mobile smart devices (e.g., smartphones, tablets), which have become commonplace today because of their convenience, have facilitated access and use of weather data for different purposes. These devices are ideal for disseminating information on a regular basis using real-time data. Programs developed for mobile smart devices are typically called "apps." There are many apps available that perform a variety of functions, and they can be personalized to the user's needs.

We developed an app called Smartirrigation Turf to provide an easy-to-use mobile tool that delivers information to improve irrigation scheduling for urban turf. By using the app instead of a set time-based schedule for irrigation, homeowners and others can easily determine the irrigation amount to turf that more closely matches water needs. The app is specifically designed for users who irrigate their turf with an automatic irrigation system and typically set it to irrigate a fixed amount on certain days without modifying

1. This document is AE499, one of a series of the Department of Agricultural and Biological Engineering, UF/IFAS Extension. Original publication date October 2013. Revised December 2019. Visit the EDIS website at https://edis.ifas.ufl.edu for the currently supported version of this publication.

2. H. K. Bayabil, assistant professor, Department of Agricultural and Biological Engineering, UF/IFAS Tropical Research and Education Center; K. W. Migliaccio, chair and professor, Department of Agricultural and Biological Engineering; J. H. Debastiani Andreis, director-systems analyst, Austn LTDA, Brazil; C. Fraisse, professor, Department of Agricultural and Biological Engineering; K. T. Morgan, professor and center director, Department of Soil and Water Sciences, UF/IFAS Southwest Florida REC; and G. Vellidis, professor, University of Georgia, Tifton Campus; UF/IFAS Extension, Gainesville, FL 32611.

The use of trade names in this publication is solely for the purpose of providing specific information. UF/IFAS does not guarantee or warranty the products named, and references to them in this publication do not signify our approval to the exclusion of other products of suitable composition.

The Institute of Food and Agricultural Sciences (IFAS) is an Equal Opportunity Institution authorized to provide research, educational information and other services

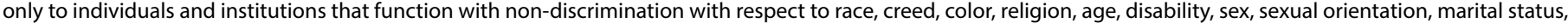

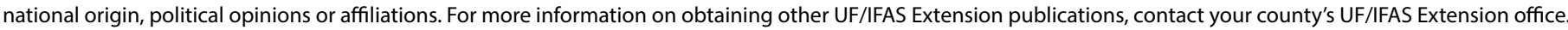
U.S. Department of Agriculture, UF/IFAS Extension Service, University of Florida, IFAS, Florida A \& M University Cooperative Extension Program, and Boards of County Commissioners Cooperating. Nick T. Place, dean for UF/IFAS Extension. 
for weather changes. Using the app to modify the irrigation schedule will reduce irrigation costs, nutrient leaching, disease, and wasted water.

The Smartirrigation Turf app is applicable in any part of the contiguous US and is compatible with iOS (iPhone, iPad, and iPod Touch) and Android devices. The app is available to download in the Apple App Store (https://t.co/ dS5o5R4zvH?amp=1) and Google Play Store (https://t.co/ ge1hZgQ1Uf?amp=1).

\section{Setting Up and Using the App}

This section provides a step-by-step guide for using the app to obtain information on how to set an automatic timer for turf irrigation. The Smartirrigation Turf app is designed for landscapes and includes cool-season turf, warm-season turf, annual flowers, woody plants and herbaceous perennials-wet climates, woody plants and herbaceous perennials-dry climates, and desert plants.

\section{Step 1. User Registration}

Once users download the app and install it on their device, they can sign in if they have an account, or register to create an account and start using the app (Figure 2). This allows the app to create an irrigation schedule specific to the site and user. Your registration information is linked to all other input data required by the app. This information is kept confidential and used solely to administer the app.

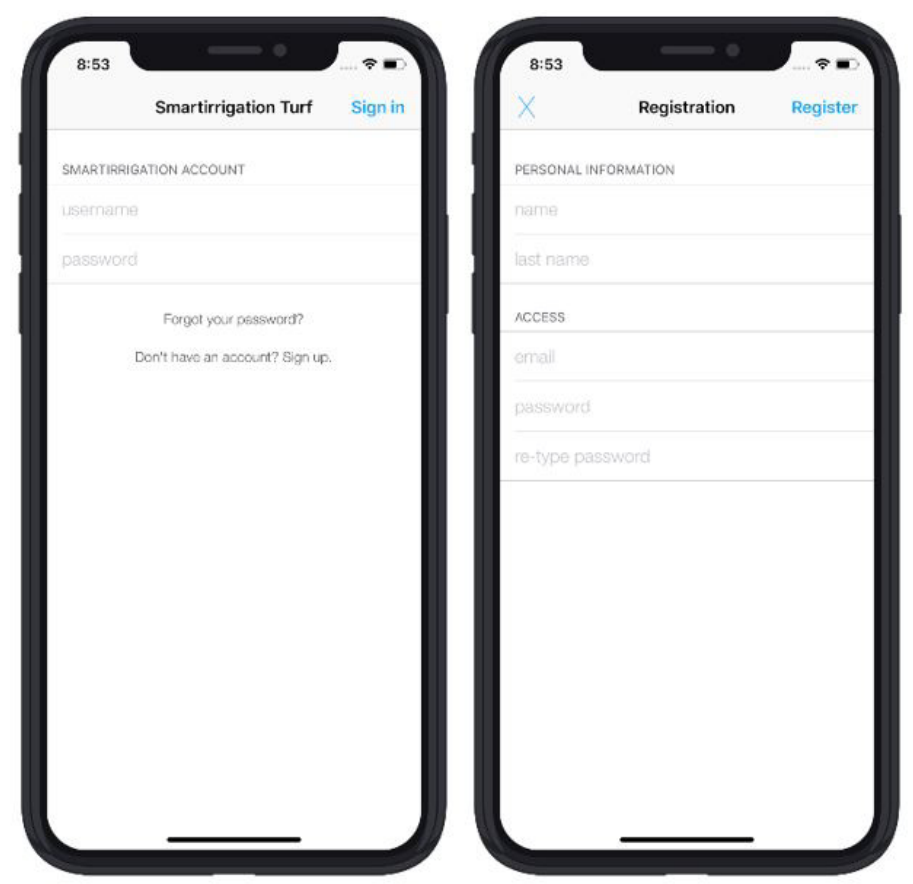

Figure 2. Login and registration screens for the Smartirrigation Turf app.

Credits: J. H. Debastiani Andreis

\section{Step 2. New Location or System}

Next, the irrigation site location must be identified (Figure 3). To do this, a small map with a movable pin is used. The pin is located at your current location by default (using the device's GPS). You can move the pin by dragging it if you are not at the irrigation system site when you are setting up the app. Identifying the location of the irrigation system correctly is important because this information links the system to the closest weather data source available.
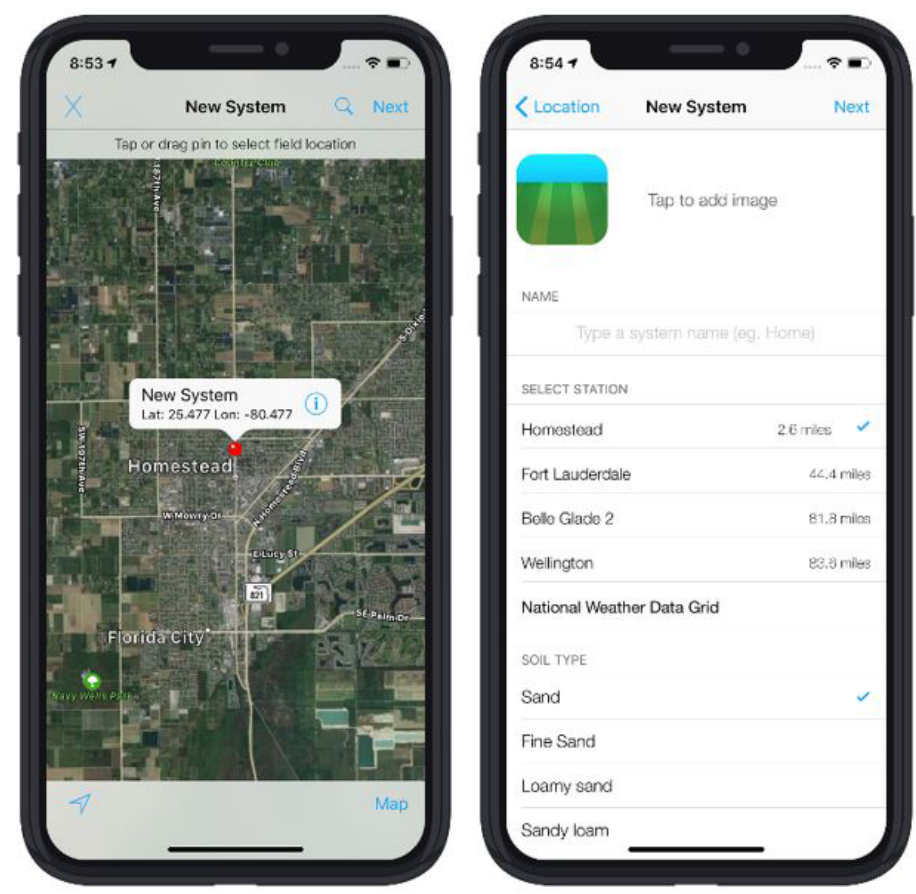

Figure 3. Location selection for new irrigation systems using the Smartirrigation Turf app.

Credits: J. H. Debastiani Andreis

Users may also take a photo of the given system for a quick visual reference. This might be useful if the app is used for multiple irrigation systems or multiple zones. You can enter descriptive names for irrigation systems, but these may be easy to forget.

On the same screen where the irrigation system location is identified, users must name the new system (Figure 3). The name should be something meaningful to the user, particularly if multiple systems will be added (e.g., "North Yard," "Pool Area," “Tom’s Backyard," etc.).

\section{Step 3. Weather Data Sources}

The irrigation schedule provided by the app is based on user inputs and site-specific weather data. The app offers two different options for weather data. The user can opt for a weather station or select the National Weather Data Grid. 
The app uses observed weather data from two weather station networks, the Florida Automated Weather Network (FAWN) and Georgia Automated Environmental Monitoring Network (AEMN). For more information about FAWN and AEMN, visit http://fawn.ifas.ufl.edu and http:// georgiaweather.net, respectively. Weather station data are included in the app only for Florida and Georgia.

Users may alternatively select the National Weather Data Grid for the weather data source. The data used are from Dark Sky (https://darksky.net) and include the continental United States.

Gridded national weather data sources provide spatially continuous weather information. However, it is important to remember that these gridded data sources provide a single value for all locations within a single pixel (data resolution). Overall, gridded rainfall products are reported to overestimate small rain events and underestimate heavy storms (Thiemig et al. 2012). If a weather station is available nearby, it is recommended that users select weather station data over gridded national weather data sources. Currently, the app does not allow users to add their own weather data. Table 1 provides a summary of a few of the limitations and benefits of weather data from gauging stations and gridded products.

\section{Step 4. Soil Information}

Next, users select the soil type from a list that includes sand, sandy loam, loam, silt loam, clay loam, and clay (Figure 4). For example, most soils in Florida are either sand or sandy loam, while the most common soils in Georgia are sandy loam or loam. If the soil type is not known, the user can obtain the needed soil texture information from the Web Soil Survey website (https://websoilsurvey.nrcs.usda.gov/ app/WebSoilSurvey.aspx).

The user also inputs the root depth. The default value for root depth is 12 inches, but it can be adjusted within a reasonable range based on user knowledge. The soil type and root depth are used to calculate soil water-holding capacity, which is the amount of water the soil can hold without losing it to drainage. This helps to ensure that the app-generated schedule does not recommend overirrigation resulting in leaching or runoff.

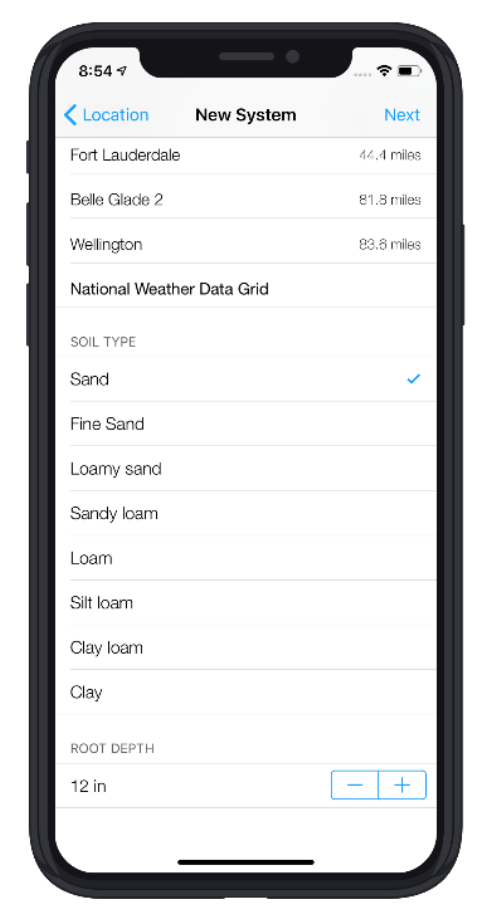

Figure 4. Inputting site soil properties using the Smartirrigation Turf app.

Credits: J. H. Debastiani Andreis

\section{Step 5. Adding Zones to the System}

In this step, users enter the irrigation system zones. Users may input multiple zones and give each zone unique characteristics (Figure 5). For each zone, users will need a name (description), plant type, sprinkler type, sprinkler rate, and days when irrigation occurs. This information should match the conditions of the user's irrigation system. The plant type relates to a crop coefficient or factor that modifies the irrigation schedule to reflect the water needs of a specific plant type. The sprinkler type can be micro, spray, multi-stream spray, gear-driven rotors, or impact sprinklers. A standard rate is provided for each sprinkler type, but the rate is adjustable if the user has better information about the system. The standard rate for micro, multistream, gear-driven rotors, and impact sprinkler types is $0.5 \mathrm{in} / \mathrm{hr}$. The standard rate for the spray sprinkler type is $1.5 \mathrm{in} / \mathrm{hr}$. Users select the days of the week when irrigation occurs by checking the day boxes. Blue coloring indicates that irrigation occurs on that day.

Many users may be subject to water restrictions that only allow irrigation on certain days. This should be considered when entering the days to irrigate. If you are unsure of current watering restrictions, check with your local water management district. Users in Florida can also check with their local UF/IFAS Extension office (http://solutionsforyourlife.ufl.edu/map/). 


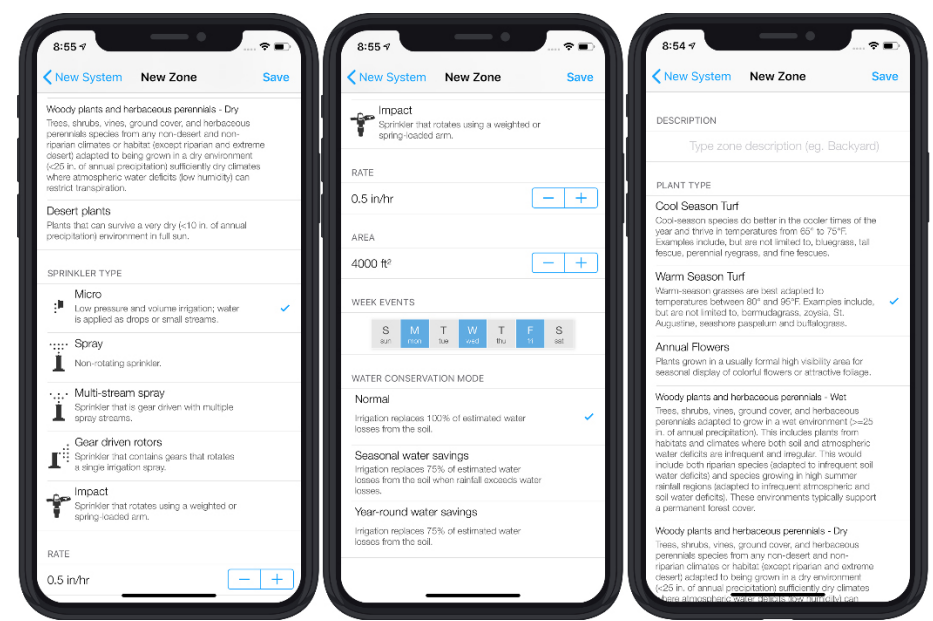

Figure 5. Inputting irrigation system information by zone using the Smartirrigation Turf app.

Credits: J. H. Debastiani Andreis

\section{Step 6. Irrigation Schedule Generated}

After finishing the irrigation system and zone input, the user should select "Save." The user will receive an irrigation schedule for each zone of the system (Figure 6). The schedule is in hours and minutes. This information is designed so that the user can easily take the recommended time schedule and modify the current automatic irrigation system. Once the system is updated with the new schedule, no further action is needed until the app notifies the user that actions should be taken.

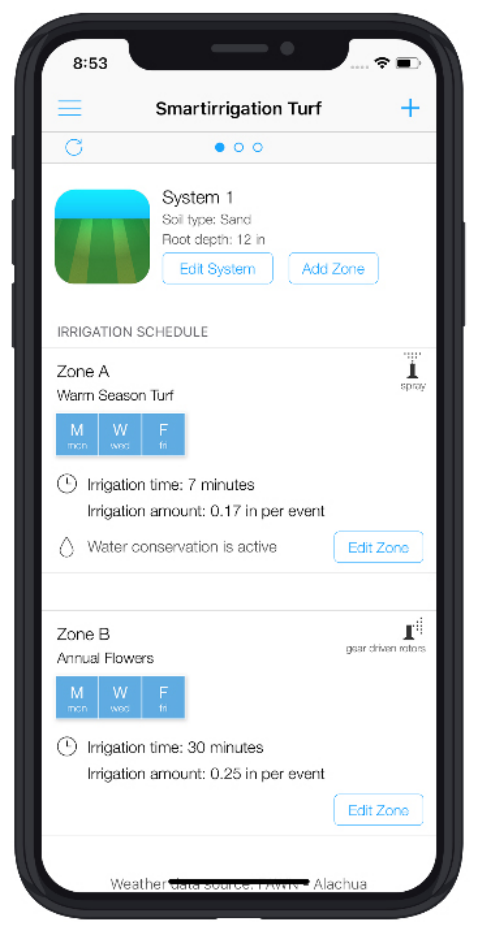

Figure 6. Irrigation schedule from the Smartirrigation Turf app. Credits: J. H. Debastiani Andreis

The app also makes sure that the irrigation amounts recommended do not exceed soil water-holding capacity. If the input data result in this circumstance, the user will receive an instruction to modify the number of irrigation days and/ or the irrigation system.

Irrigation is calculated using the FAO Penman-Monteith method to estimate reference evapotranspiration (ET) with region-specific crop coefficients $\left(\mathrm{K}_{\mathrm{c}}\right)$ (Zotarelli et al. 2010). Crop coefficients used are provided in Table 2 and Table 3 This version of the tool considers irrigation to be equal to $\mathrm{ET}_{\mathrm{c}}$ where: $\mathrm{ET}_{\mathrm{c}}=\mathrm{K}_{\mathrm{c}}{ }^{*} \mathrm{ET}_{\mathrm{o}}$.

Irrigation schedules are determined by averaging the last five days of reference evapotranspiration (ET) and multiplying by the appropriate crop coefficient. Every 15 days a new schedule is determined, and users receive a notification that their schedules need to be changed (Figure 7).

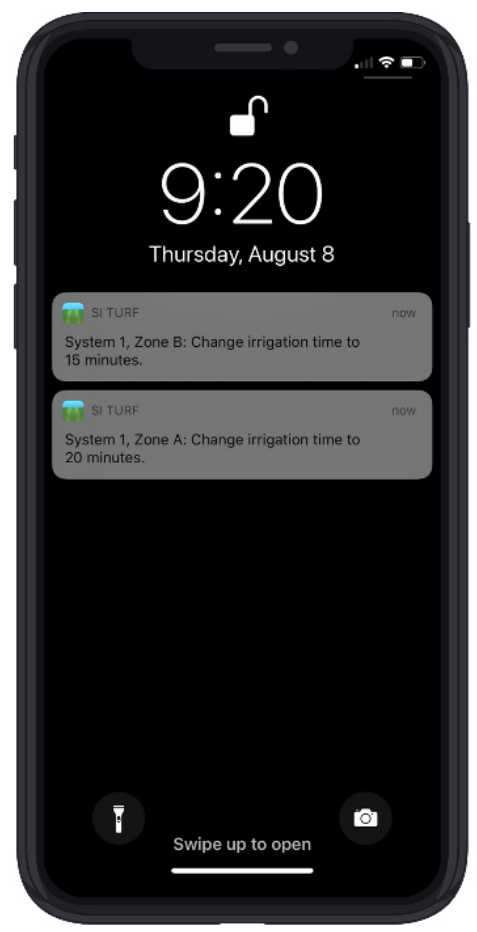

Figure 7. Notification received with a new irrigation schedule using the Smartirrigation Turf app.

Credits: J. H. Debastiani Andreis

\section{Step 7. Weather Forecast Information}

In addition to providing a real-time irrigation schedule, the app also provides current conditions, forecasts of temperature and rainfall probability for the next few hours, and estimates of high and low temperatures, relative humidity, rainfall probability, and wind speed for the next five days (Figure 8). Forecast information can be found using the menu in the app. Forecast data are provided by the National Weather Service (NWS). For more information about NWS, visit http://weather.gov. 


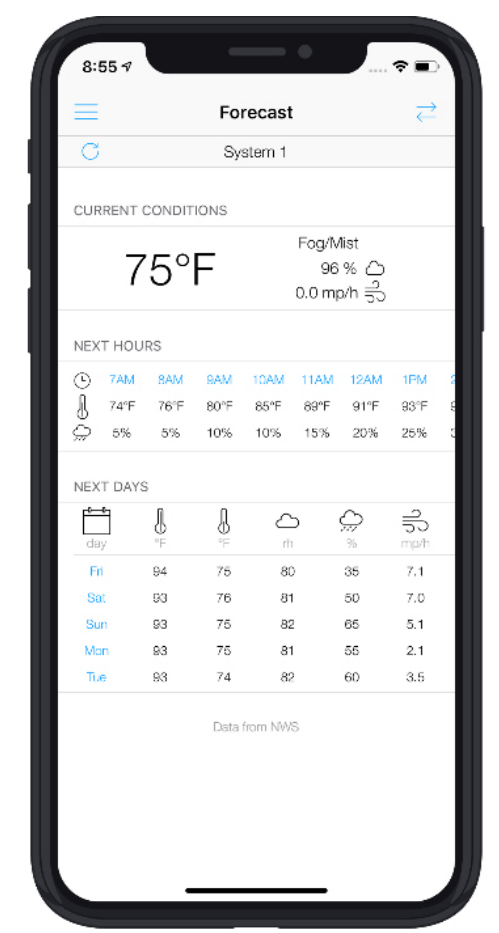

Figure 8. Weather forecast information provided by the Smartirrigation Turf app.

Credits: J. H. Debastiani Andreis

App users receive notifications if more than 0.4 inches of rain occurs 24 hours prior to irrigation. An example notification for such an event is, "A rain event occurred in (your location) area. Please check (your irrigation zone) and skip tomorrow's irrigation if appropriate." Notifications are also sent if the probability of rain is higher than $60 \%$ for the next 24 hours. An example would be, "There is over $75 \%$ chance of rain for (your system) area in the next 24 hrs. Adjust irrigation as appropriate" (Figure 9). Historical notifications are accessible in the app using the menu (Figure 10). Users receive notifications to further refine their irrigation schedules to minimize the occurrence of irrigation-generated runoff or drainage.

\section{Using the App}

Once you install the app and enter information specific to your site, the app is working! Use the app schedule to set the timer on the automatic irrigation system by zone. Next, read app notifications and alter the schedule as needed. No additional changes are needed to the app unless there is a change in the irrigation system.

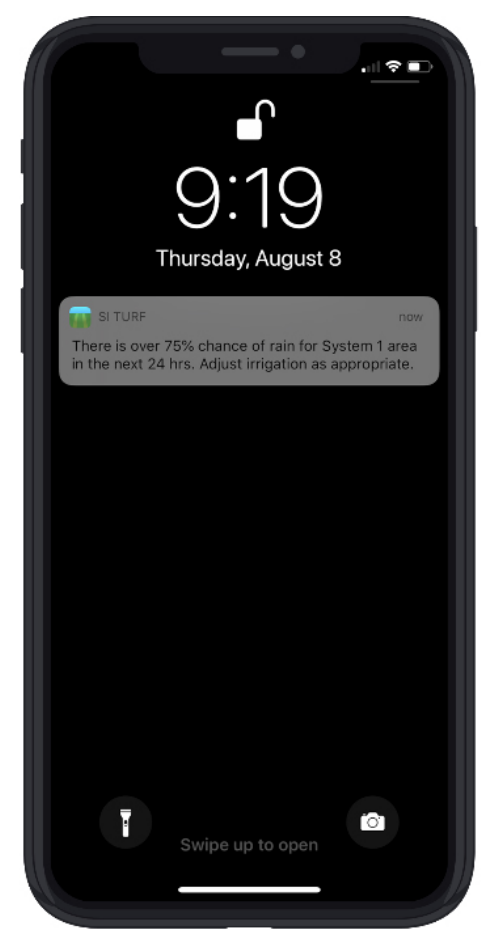

Figure 9. Notification received from the Smartirrigation Turf app alerting the user of the high probability of rain in the next 24 hours. Credits: J. H. Debastiani Andreis

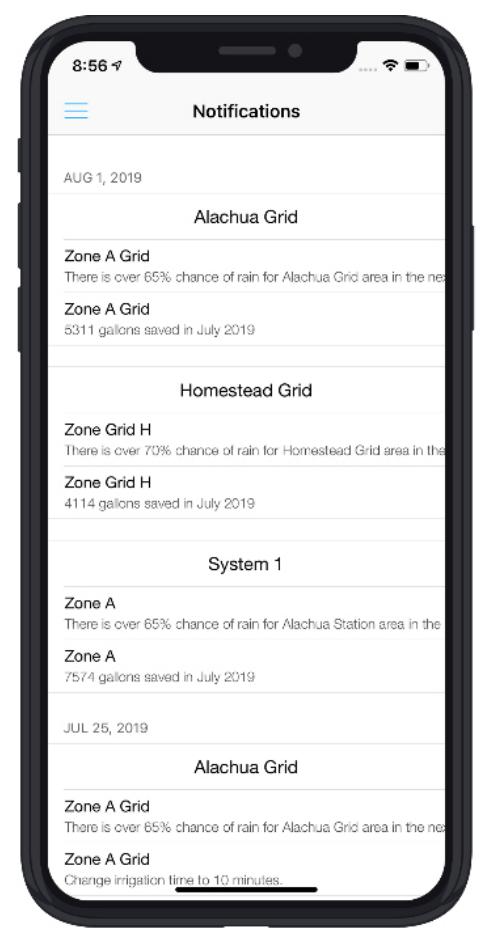

Figure 10. Using the menu, users can look at all recent notifications received from the app.

Credits: J. H. Debastiani Andreis

\section{Conclusion}

The Smartirrigation Turf app provides an easy way to determine your irrigation schedule for better management of turf. The irrigation schedule is based on real-time $\mathrm{ET}_{\text {o }}$ data at a weather station near the system location when available or gridded national weather data from the Dark 
Sky website (https://darksky.net). Using this app for irrigation is expected to reduce irrigation amounts annually by $25 \%-30 \%$ if the app-suggested schedules are followed. For more information, visit the Smartirrigation Apps website (http://smartirrigationapps.org) or refer to Migliaccio et al. (2015).

\section{Acknowledgment}

Funding for this app was provided by a USDA NIFA National Integrated Water Quality grant.

\section{References}

Davis, S. L., and M. D. Dukes. 2010. "Irrigation scheduling performance by evapotranspiration-based controllers." Agric. Water Mgmt. 98(1): 19-28.

Irrigation Association. 2008. Smart Water Application Technologies (SWAT), Climatologically Based Controllers, Eighth Testing Protocol. Falls Church, VA: SWAT Committee.

Jia, X., M. D. Dukes, and J. M. Jacobs. 2009. “Bahiagrass crop coefficients from eddy correlation measurements in central Florida." Irrig. Sci. 8(1): 5-15.

Migliaccio, K. W., K. T. Morgan, C. Fraisse, G. Vellidis, and J. H. Andreis. 2015. "Performance evaluation of urban turf irrigation smartphone app." Computers and Electronics in Agriculture 118: 136-142.

NASA. 2005. "More lawns than irrigated corn." Accessed on May 4, 2019. https://earthobservatory.nasa.gov/features/ Lawn/lawn2.php

Romero, C., and M. D. Dukes. 2011. Net Irrigation Requirements for Florida Turfgrass Lawns: Part 3-Theoretical Irrigation Requirements. AE482. Gainesville: University of Florida Institute of Food and Agricultural Sciences. http:// edis.ifas.ufl.edu/ae482

Stewart, E. H., and W. C. Mills. 1967. "Effect of depth to water table and plant density on evapotranspiration rate in southern Florida." Transactions of ASAE 12(5): 646-647.

Thiemig, V., R. Rojas, M. Zambrano-Bigiarini, V. Levizzani, and A. De Roo. 2012. "Validation of satellite-based precipitation products over sparsely gauged African river basins." Journal of Hydrometeorology 13: 1760-1783. https:// doi.org/10.1175/JHM-D-12-032.1

Zhang, M., C. de Leon, and K. Migliaccio. 2018. "Evaluation and comparison of interpolated gauge rainfall data and gridded rainfall data in Florida, USA.” Hydrological Sciences Journal 63: 561-582. https://doi.org/10.1080/02626667.201 8.1444767

Zotarelli, L., M. D. Dukes, C. C. Romero, K. W. Migliaccio, and K. T. Morgan. 2010. Step by Step Calculation of the Penman-Monteith Evapotranspiration (FAO-56 Method). AE459. Gainesville: University of Florida Institute of Food and Agricultural Sciences. http://edis.ifas.ufl.edu/ae459 
Table 1. Summary of a few limitations and benefits of weather data sources.

\begin{tabular}{|l|l|l|l|}
\hline & Weather Station Data & Gridded Data \\
\hline Benefits & - $\begin{array}{l}\text { Directly measured data } \\
\text { More representative of actual } \\
\text { conditions }\end{array}$ & $\begin{array}{l}\text { More reliable } \\
\text { Limitations }\end{array}$ & $\begin{array}{l}\text { Spatially continuous data } \\
\text { Data available for all locations within range } \\
\text { Mostly available for free }\end{array}$ \\
\hline & - $\begin{array}{l}\text { Spatially noncontinuous and } \\
\text { unavailable for all locations }\end{array}$ & $\begin{array}{l}\text { Indirect measurements (based on satellite, radar, and gauge } \\
\text { interpolations) } \\
\text { Single value per pixel, which could be a few square miles }\end{array}$ \\
\hline
\end{tabular}

Table 2. Monthly crop coefficient $\left(\mathrm{K}_{\mathrm{c}}\right)$ values used to estimate warm-season turf irrigation schedules in the Smartirrigation Turf app.

\begin{tabular}{|c|c|c|c|c|}
\hline \multirow[b]{2}{*}{ Month } & \multicolumn{3}{|c|}{ K Values } & \multirow[b]{2}{*}{$\begin{array}{c}\text { Irrigation } \\
\text { Association }^{5}\end{array}$} \\
\hline & Panhandle/North Florida ${ }^{1,2}$ & Central/Southwest Florida ${ }^{1,3}$ & South Florida ${ }^{1,4}$ & \\
\hline $\begin{array}{l}\text { January } \\
\text { February } \\
\text { March } \\
\text { April } \\
\text { May } \\
\text { June } \\
\text { July } \\
\text { August } \\
\text { September } \\
\text { October } \\
\text { November } \\
\text { December }\end{array}$ & $\begin{array}{l}0.35 \\
0.35 \\
0.55 \\
0.80 \\
0.90 \\
0.75 \\
0.70 \\
0.70 \\
0.75 \\
0.70 \\
0.60 \\
0.45\end{array}$ & $\begin{array}{l}0.45 \\
0.45 \\
0.65 \\
0.80 \\
0.90 \\
0.75 \\
0.70 \\
0.70 \\
0.75 \\
0.70 \\
0.60 \\
0.45\end{array}$ & $\begin{array}{l}0.71 \\
0.79 \\
0.78 \\
0.86 \\
0.99 \\
0.86 \\
0.86 \\
0.90 \\
0.87 \\
0.86 \\
0.84 \\
0.71\end{array}$ & $\begin{array}{l}0.52 \\
0.64 \\
0.70 \\
0.73 \\
0.73 \\
0.71 \\
0.69 \\
0.67 \\
0.64 \\
0.60 \\
0.57 \\
0.53\end{array}$ \\
\hline \multicolumn{5}{|c|}{$\begin{array}{l}{ }^{1} \text { Crop coefficients used in the model based on ZIP code } \\
2 \text { Jia et al. (2009) } \\
{ }^{3} \text { Davis and Dukes (2010) } \\
{ }^{4} \text { Stewart and Mills (1967); Romero and Dukes (2011) } \\
{ }^{5} \text { Values used for regions outside Florida; Irrigation Association (2008) }\end{array}$} \\
\hline
\end{tabular}

Table 3. Crop coefficient $\left(\mathrm{K}_{\mathrm{c}}\right)$ values used to estimate irrigation schedules in the Smartirrigation Turf app (ANSI/ASABE S623 Standard).

\begin{tabular}{|l|l|}
\hline \multicolumn{1}{|c|}{ Plant Type } & $\mathbf{K}_{\mathrm{c}}$ \\
\hline Turf, cool season & 0.8 \\
\hline Annual flowers & 0.8 \\
\hline Woody plants and herbaceous perennials, wet climate & 0.7 \\
\hline Woody plants and herbaceous perennials, dry climate & 0.5 \\
\hline Desert plants & 0.3 \\
\hline
\end{tabular}

